\title{
HOSPITAL SUPERVISORY BOARD ROLE IN MEDICAL DISPUTE SETTLEMENT IN HOSPITAL (Analysis toward Mechanism and Normative Obstacles) ${ }^{\Omega}$
}

\author{
Nayla Alawiya, Aryuni Yuliantiningsih, Dessi Perdani Yuris Puspita Sari \\ Faculty of Law Jenderal Soedirman University Purwokerto \\ E-mail: nayllaw86@gmail.com
}

\begin{abstract}
Health services are not always able to deliver the results expected by the patient or the patient's family. The gap often makes the dissatisfaction that arises medical disputes, including disputes in the hospital. Law No. 44 of 2009 on the Hospital Board of Supervisors ordered the establishment of the Hospital that one role is to resolve disputes hospital. But government regulation of the Hospital Board of Supervisors recently issued in August 2013, and setting the Hospitals Act does not mention the prior regulations promulgated which raises normative barriers. The method used is normative. Results of this study is that the Supervisory Board has the task Central Hospital preparing procedures for handling complaints and mediation, while receiving the complaint and make efforts to resolve the dispute by way of mediation is the Supervisory Board Provincial Hospital. Hospital Board of Supervisors province can not perform tasks because the procedures for complaints and mediation has not been established by the Board of Supervisors Hospital Center. Law No. 44 Year 2009 has a setting that is not in sync with Act No. 39 of 2009 and Law No. 29 of 2004.
\end{abstract}

Keywords: health law, normative barriers, dispute resolution, hospitals

\begin{abstract}
Abstrak
Pelayanan kesehatan tidak selalu bisa memberikan hasil yang diharapkan oleh pasien atau keluarga pasien. Kesenjangan inilah yang sering menjadikan ketidakpuasan sehingga timbul sengketa kesehatan, termasuk sengketa di rumah sakit. Undang-Undang No. 44 Tahun 2009 tentang Rumah Sakit memerintahkan dibentuknya Badan Pengawas Rumah Sakit yang salah satu perannya adalah menyelesaikan sengketa rumah sakit. Akan tetapi peraturan pemerintah tentang Badan Pengawas Rumah Sakit baru dikeluarkan pada bulan Agustus 2013 dan pengaturan dalam Undang-Undang Rumah Sakit tidak menyinggung peraturan terkait yang terlebih dahulu diundangkan sehingga memunculkan hambatan normatif. Metode penelitian yang digunakan adalah yuridis normatif. Hasil penelitian ini adalah bahwa Badan Pengawas Rumah Sakit Pusat memiliki tugas menyusun tata cara penanganan pengaduan dan mediasi, sedangkan yang menerima pengaduan serta melakukan upaya penyelesaian sengketa dengan cara mediasi adalah Badan Pengawas Rumah Sakit Provinsi. Badan Pengawas Rumah Sakit provinsi belum bisa menjalankan tugas karena tata cara pengaduan dan mediasi belum dibentuk oleh Badan Pengawas Rumah Sakit Pusat. Undang-Undang No. 44 Tahun 2009 memiliki pengaturan yang tidak sinkron dengan Undang-Undang No. 39 Tahun 2009 dan Undang-Undang No. 29 Tahun 2004.
\end{abstract}

Kata kunci: hukum kesehatan, hambatan normatif, penyelesaian sengketa, rumah sakit

\section{Introduction}

The relationship between patients with health workers in hospitals included in the scope of contract law. Legal relationship between hospitals/doctors and patients derived from the agreement, happened as a result of their deal. Agreement between hospital/doctors and patients named as a therapeutic agreement. ${ }^{1}$ As a treaty, it appears rights and obligations as a result

$\Omega$ This scientific article is the essence of the results of research funded by DIPA Jenderal Soedirman University with research Contract No. 2542/UN23.10/PN/2013 on May 6, 2013.

Faiz Mufidi and Sri Pursetyowati, “Dispute Settlement in Medical Hospital", Jurnal Ilmu Hukum Wacana Paramarta, Vol. 8 No. 1 2009, Bandung: Faculty of Law Langlangbuana University, page 23. 
of the agreement. ${ }^{2}$ Principal engagements which arise in the therapeutic agreement is the obligation of doctor to perform medical efforts and the right of patients on the medical efforts, the patient obligation to pay honorarium to doctor after his medical efforts and the right of doctor on the payment of the honorarium. ${ }^{3}$ This implementation of the rights and obligations that often led to disputes. The trigger of disputes in hospitals are misunderstandings, differences in interpretation, unclear arrangements, dissatisfaction, offense, suspicion, inappropriate actions, fraudelent or dishonest, arbitrariness or injustice, and the occurrence of unforeseen circumstances. ${ }^{4}$

Lately the dispute between doctor and patient is often happens, even from some of the conflict involving the hospital as one of the heaIth facilities. Results of research in Semarang, there were 20 cases involved patients sued the hospital (in private hospitals), 15 cases sued the government hospitals and education hospitals. ${ }^{5}$

Dispute in hospital is not only related to the medical staff who work in there, but also can relate to the hospital as a legal entity, such as land disputes and environmental disputes. Shella Tiara hospital Bengkulu obtain environ-mental pollution lawsuit and experienced cons-traints in hospital operating license extension. ${ }^{6}$

Dispute settlement can be used two fascia, which are litigation (court) and non litigation/ consensual/non-adjudication. ${ }^{7}$ Dispute settlement through litigation has an open charac-ter, requires a lot of time, following the formal judicial procedure, requiring lawyers and ended with a win or lose. Non-litigation dispute settlement are closed, do not require a lawyer and flexible. Non-litigation dispute resolution efforts can be done through mediation.

2 Arif Nuryanto, "Model Perlindungan Hukum Profesi Dokter", Jurisprudence, Vol. 8 No. 1. July 2012, Surakarta: Muhammadiyah University Surakarta, page 2.

3 Bambang Sukarjono, "Liabilitas Hukum Pihak Rumah Sakit terhadap Pasien (Studi tentang Perlindungan Konsumen/ Pasien dan Tanggung Jawab Pihak Rumah Sakit dalam Transaksi Terapeutik pada Rumah Sakit Islam Siti Aisyah Kota Madiun)", Sosial, Vol. 10 No. 2 September 2009, Malang: STIE Malangkucecwara, page 33.

4 Dedi Afandi, "Mediasi: Alternatif Penyelesaian Sengketa Medis, Majalah Kedokteran Indonesia", Vol. 59 No. 5 May 2009, Jakarta: University of Indonesia, page 189.
Since October 28, 2009 Indonesia has Law No. 44 Year 2009 on Hospitals. Law of Hospital commanding establishment of the Hospital Supervisors Board on national and provincial level. One of the tasks of the Supervisory Board Hospital in Provincial, as mentioned in Article 60 is to receive complaints and conduct mediation by way of mediation. Previously, if the parties agree to use the settlement of disputes as mediation, it only involves the hospital with the patient or those who feel harmed, as well as a mediator if necessary. But still there is aggrieved party whether from hospital or the injured party by the hospital which directly sued to court. After the existment of Hospital statute, the hospital must try to settle the dispute through mediation and proposed to Supervisory Board of the pro-vincial hospital, so expect a case like Prita did not happen again.

Hospital dispute settlement mechanisms are not explicitly regulated in the Law of Hospital, only a section of the establishment of the Supervisory Board of the Provincial Hospital which one of its tasks to tackle the dispute by way of mediation. This is interesting to studied, related to the mechanism of hospital disputes settlement and arrangement of normative obstacles on dispute settlement mechanism in hospital.

\section{Problems}

The main problem of this research are: first, how is the role of the Supervisory Board of the Hospital in the medical dispute settle-ment in the hospital?, and second, what are the obstacles on normative role of the Supervisory Board of the Hospital?

\section{Research Methods}

5 Endang Kusuma Astuti, “Tanggung Gugat Dokter dan Rumah Sakit Kepada Pasien Pada Kegagalan Pelayanan Medis di Rumah Sakit", Jurnal Masalah-Masalah Hukum, Vol. 40 No. 2 April 2011, Semarang: Faculty of Law Dipo-negoro University Semarang. page 173.

6 Radar Bengkulu, Kasus RS Tiara Shella Juga Bergulir ke PTUN, http://radarbengkulu.web.id/ published on July, 5 2012, accesed on March, 102013.

7 Dedi Afandi, Op.cit, page 190. 
This study uses a type of normative juridical research using several approaches problems that include statute approach, analytical approach and the conceptual approach. Specifications research is prescriptive. The research focused on the study of the principles of law, synchronization law and systematic law. Data used is secondary data with literature data collection methods and qualitative methods of normative analysis.

\section{Discussion}

The role of the Supervisory Board of the Hospital in Medical Dispute Settlement in Hospital

Many health problems and medical problems can not be dealt with and solved in the doctor's office, out patient clinic or at the patient's home. Therefore, the hospital held as equitable health care and as a place to meet the various demands of patients and doctors, so that problem solving can be conducted as well. ${ }^{8}$

The risks that occur in human beings so susceptible to an action, if it is not done carefully and thoroughly will have consequences to fatal error (medical risk). ${ }^{9}$ Hospital as a medical services is an institution that is very complex and high risk, especially in regional and global environmental conditions which its changes are very dynamic. Therefore, hospitals are required to be able to manage its activities, with emphasis on the responsibility of health professionals, particularly medical and nursing staff in performing their duties and authority. ${ }^{10}$

Health Services by health professional in hospitals are not always able to deliver results that in line with the expectations of all parties. If the patient proved to be harmed by health care at the hospital, then the patient can ask for accountability from the hospital. Article 46 of Law No. 44 Year 2009 on hospital determines that the hospital is legally responsible for all the losses incurred over the negligence of health professionals in hospitals.

Endang Kusuma Astuti. Op.cit. page 170.

Boedi Santoso Irianto, "Suatu Tinjauan Malpraktik dalam Hukum Kesehatan”. Themis. Vol. 2 No. 1 October 2007, Jakarta: Pancasila University, page 78.

10 Setya Wahyudi, "Tanggung Jawab Rumah Sakit terhadap Kerugian Akibat Kelalaian Tenaga Kesehatan dan Implikasinya", Jurnal Dinamika Hukum, Vol. 11 No. 3, September
Judging from the type of the consequences of an unlawful act, in particular unlawful act against the human's body, the compensation may be granted if there is one of the elements as follow. First, the economic losses, such as medical expenses and hospital; second, injury or disability of the victim's body; third, the physical pain; and the mentally ill, such as stress, despondent, excessive hostility, anxiety, and other mental disorders/mind. ${ }^{11}$ However, health services which the result are inspanningverbintenis often led to disagreements between the patients with the hospital or disputes arise.

Dispute of the hospital can be defined by three meanings. First, there is a medical dispute and the dispute should be settled in the hospital. It means that the hospital only as a medical dispute settlement. Secondly, there is a medical dispute and the hospital as one of the subjects in the dispute. Third, institutional dispute unrelated hospital medical, such as land disputes or the environment. The first and second meaning is very likely to occur as a result of medical services that occur in hospitals. The first one shows the understanding there is a dispute between a doctor or other medical profession as a medical service provider and the recipient of medical services over the ridge of the medical services that occur in hospitals. Those understanding both showed the hospital as a medical service provider and the recipient of medical service dispute. Disputes related hospital medical services is what will be discussed.

Dispute settlement can be used two fascia, which are litigation (court) and non litigation/ consensual/non-adjudication. We can all understand that the proceedings in the court process is costly and consuming time. The conventional court system which naturally opposite, oftenly the result in one party as winners and others as losers. While the criticism of the judiciary in carrying out its functions were considered too den-

2011, Purwokerto: Faculty of Law Jenderal Soedirman University, page 505.

11 Bambang Heryanto, "Malpraktik Dokter dalam Perspektif Hukum”, Jurnal Dinamika Hukum, Vol. 10 No. 2 May 2010, Purwokerto: Faculty of Law Jenderal Soedirman University, page 191. 
se, slow and time wasting, expensive and less responsive to the public interest and its considered too formalistic and too technical. ${ }^{12}$ That is why the reconsideration problem of the justice improvement system towards the effective and efficient happening in everywhere, although this time the court that handles civil disputes must seek peace through mediation build upon Supreme Court Regulation No. 1 of 2008.

Dispute settlement through mediation is also regulated in Law No. 30 of 1999 on Arbitration and Alternative Dispute Settlement. Based on the law of alternative dispute settlement include consultation, negotiation, mediation, conciliation or expert assessment. Disputes related to the hospital, generally occurs between the hospital with the patient and family. At the time of the patient and the family felt unsatisfactory service or irregularities in medical action, the patient and the family will make a complaint against the hospital. At the time the complaints process is the patient and family will meet with the medical committee that in the hospital.

Complaints of patients and families can be proceed to Indonesian Medical Disciplinary Council Medical Committee (MKDKI) if the hospital is not able to settle the dispute. Law No. 29 Year 2004 on Medical Practice is the legal basis for the establishment of MKDKI. Article 64 of Law No. 29 of 2004 determines MKDKI duties include receiving complaints, examine and decide cases of violation of discipline doctors and dentists are submitted and to develop guidelines and procedures for handling cases of discipline violation doctor or dentist.

Complaints which submitted to MKDKI not eliminate the right of every person to report alleged criminal offenses to the relevant authorities and/or civil disadvantages sued to court. MKDKI examine and give a decision on the complaints relating to discipline doctors and dentists. If the inspection found violations of ethics, MKDKI proceeds the complaint to the professional organizations. MKDKI decision binding doctors, dentists, and the Indonesian Medical Council.
Need to realize that the dispute in the hospital is not only related to the doctor. Dispute in the hospital may be related to other health professionals besides doctors who are not specifically regulated on the settlement of disputes with their respective professions and can also be related to the environment or land. Every profession and field requires agencies to deal with dispute settlement, where each formed dispute settlement institutions, it will result in the emergence of many new institutions and swelling state budget. Hospital as a complex organization if it has a dispute although only caused by a health worker, it will have a negative impact on the hospital's image in the public eye. Those things are the basis of the need to establish a special body to deal with disputes hospital.

Since October 28, 2009 Indonesia has Law No. 44 Year 2009 on Hospital (here in after referred to as the Law of Hospital). Law of Hospital commanding establishment of the Hospital Supervisors Board on national and provincial level. Article 60 of Law No. 44 Year 2009 on Hospital determined that the Supervisory Board in charge of Provincial Hospital are: first, monitoring and maintaining the rights and obligations of patients in the region; second, supervising the implementation of the Hospital ethics, professional ethics, and legislation; third, reporting monitoring results to the Indonesia Hospital Supervisors Board; fourth, analyzing the results of the monitoring and providing recommendations to the Regional Government for used as guidance; fifth, receiving complaints and doing effort to settle disputes by way of mediation; sixth, used as guidance; and seventh, receive complaints and conduct mediation by way of mediation.

Before the enactment of the Law of Hospital, if the parties agree to use the settlement of disputes by mediation, it only involves the hospital with the patient or those who feel harmed, as well as the mediator agreed upon by both parties. After the establishment of the Supervisory Board of the Provincial Hospital, there is exist a special agency that receive complaints and dispute settlement to handle the hospital.

12 Dedi Afandi, Op.cit, p. 190. 
Related to hospital dispute settlement mechanism has not been regulated in the Law of Hospital. On July 8, 2013 the President set the Government Regulation No. 49 Year 2013 Hospital Board Supervisors. Article 5 of Government Regulation No. 49 In 2013 determines that the BPRS has the authority to: first, arrange procedures for handling complaints and mediation by SRB Province; second, arrange guidelines, reporting systems, and information systems and networks from BPRS and BPRS to be determined by the Provincial Minister; third, ask for the reports from BPRS and make clarifications regarding public complaints and mediation; fourth, ask for a report on the results of the guidance and supervision of BPRS Province; fifth, request information and coordination with the Provincial BPRS, government agencies, and agencies; sixth, related to draft guidelines on hospital surveillance and establish reporting systems and information systems; seventh, provide recommendations to the Minister and the governor about guidance and supervision patterns of Hospital based on the results analysis of guidance and supervision; eighth, propose the establishment of Provincial BPRS to the governor; ninth, provide recommendations to the Minister and Local Government to take administrative action against the Hospital which offense.

Article 24 of Government Regulation No. 49 In 2013 determines that Provincial BPRS has to: first, monitoring and maintaining the rights and obligations of patients in the region; second, monitoring and maintaining the rights and obligations of Hospital in the region; third, supervising the implementation of the Hospital ethics, professional ethics, and legislation; fourth, reporting the results of monitoring to BPRS; fifth, analyzing the results of the monitoring and providing recommendations to the Regional Government for use as guidance material; and sixth, receiving complaints and doing effort to settle disputes by way of mediation.

Based on the provisions of the Government Regulation No. 49 In 2013 there is a new provision related to the dispute settlement mechanism of the hospital, through an independent non-structural unit in the form of Central BPRS and Province BPRS. Central BPRS has the task to arrange procedures for handling complaints and mediation, while receiving the complaint and make efforts to settle the dispute by way of mediation is Province BPRS task. Mediation conducted by the Province BPRS still have the possibility to be not successful or is not reached an agreement. The next efforts that can be taken by the patient and family is seeks the court. Supreme Court Regulation No. 1 of 2008 determines that courts dealing with the civil disputes must seek peace through mediation. It shows that no provision of Province BPRS mediation results are final makes the process of disputes settlement by the Province BPRS become ineffective.

Normative Obstacles in Role of the Hospital Supervisory Board in Medical Dispute Settlement in Hospital

Normative obstacles can be done with the analysis of legislation synchronization. Theory which used is the theory of Hans Kelsen, known as stufentheorie. According to Hans Kelsen (1881-1973), law is the written legislation. In relation to the hierarchy of legal norms, Hans Kelsen argued Stufentheorie about the level of legal norm, legal norms were tiered and layered in a hierarchical arrangements. A lower norms applicable, sourced, and based on a higher norm, the norm of higher force, sourced and based on the norms of higher again. And so on up to a norm that can not be traced further and hypothetical and fictional, that Norma Basic (Grund-norm). ${ }^{13}$

Basic norm is a norm which is determined in advance by the public and a hanger for the norms of a hanger for the norms that are below, so that a basic norm said pre supposed. In the case of arrangements/hierarchical system of nor$\mathrm{ms}$, if the basic norms that change would be corrupted system of norms that exist underneath. For the sake of legal certainty, a law must not conflict with other laws and some regulations

13 Maria Farida Indrati, 2007, Ilmu Perundang-Undangan, Jenis, Fungsi dan Materi Muatan, Yogyakarta: Kanisius. page 41. 
must not conflict with either the above rules, or regulations that beside. ${ }^{14}$

Forms of dispute settlement policy that is the latest hospital regulated in Law No. 44 Year 2009 on Hospitals and Government Regulation No. 49 Year 2013 on the Board of Trustees Hospital. However, there is Law No. 29 Year 2004 on Medical Practice were first enacted. Article 55 of the Medical Practice Act ordered the establishment of the Indonesian Medical Disciplinary Council that one of the duties are receiving the complaint, examine and decide cases of violation of discipline doctors and dentists are submitted.

Doctors and dentists are part of the health professionals who work in hospitals. Dispute setlement arrangements related to doctors and dentists are contained in the Medical Practice Act has been first implemented and still valid after the Law Hospital. However, the Act does not include the Hospital of the Medical Practice Act within "remembering" and did not mention specifically the profession of doctors and dentists who are already regulated by law. Thus there are discrepancies between the Law Hospital with the Medical Practice Act.

Related to dispute settlement should use the mechanisms stipulated in the Law Hospital and government regulation of the SRB. Under both these rules, dispute settlement SRB hospital complained to the province and settled through mediation. Complaints to the SRB cannot be done if the province related to violations of discipline doctors and dentists are detrimental to the patient, because there has been MKDKI regulated by the Medical Practice Act which is lex specialist. MKDKI receive complaints related to violation of discipline by doctors and dentists which can be disputed hospital. MKDKI only decide whether doctors and dentists who have complained of violations of discipline and provide penalties for violations, but did not open settlement by way of mediation. It shows that the dispute with the doctors and dentists in hospitals cannot be reported to the Provincial BPRS.
Dispute settlement through mediation pursued by the Provincial SRB did not rule out a possibility to failure or not an agreement. The next efforts that can be taken by the patient and family is the courts. Supreme Court Regulation No. 1 of 2008 determines that courts dealing with civil disputes must seek peace through mediateon. It shows that no provision of Provincial BPRS mediation results are final, becoming efficient dispute settlement on normative obstacles medical.

\section{Closing \\ Conclusion}

Law No. 44 Year 2009 commanded the establishment of the National Agency of Indonesia's Hospital and the Provincial Hospital Board of Supervisors. Government Regulation No. 49 In 2013 determines that the Center BPRS has the task of arrange procedures for handling complaints and mediation, while receiving the complaint and make efforts to resolve the dispute by way of mediation was Provincial BPRS.

Medical dispute settlement in the hospital should use the mechanism set out in the Law Hospital and Government Regulation on BPRS which determining the complaint submitted to the Province and settled through mediation. Complaints to the BPRS cannot be done if the province related to violations of discipline doctors and dentists are detrimental to the patient, because there has been MKDKI regulated by the Medical Practice Act which is lex specialist. Dispute settlement through mediation attempted by Province BPRS also did not rule out the possibility of failure. The absence of provisions that Province BPRS mediation results are final, becoming effiecient dispute settlement on normative obstacles medical.

\section{Suggestion}

There are several things that can be done to improve the role of BPRS in medical dispute settlement in the hospital. First, BPRSI immediately issue rules regarding procedures for handling complaints and mediation of medical dispu-

14 Ibid. page 42-43. 
tes in the hospital. Secondly, SRB province immediately activated in each province. Third, the revision of Law No. 24 of 2009 on Medical Practices.

\section{References}

Afandi, Dedi. "Mediasi: Alternatif Penyelesaian Sengketa Medis". Majalah Kedokteran Indonesia", Vol. 59 No. 5 May 2009. Jakarta: University of Indonesia;

Astuti, Endang Kusuma. “Tanggung Gugat Dokter dan Rumah Sakit Kepada Pasien pada Kegagalan Pelayanan Medis di Rumah Sakit". Jurnal Masalah-Masalah Hukum, Vol. 40 No. 2 April 2011. Semarang: Faculty of Law Diponegoro University Semarang.

Heryanto, Bambang. "Malpraktik Dokter dalam Perspektif Hukum". Jurnal Dinamika Hukum, Vol. 10 No. 2 May 2010 Edition, Purwokerto: Faculty of Law Jenderal Soedirman University;

Indrati, Maria Farida. 2007, Ilmu Perundang-Undangan, Jenis, Fungsi dan Materi Muatan. Yogyakarta: Kanisius.

Irianto, Boedi Santoso. "Suatu Tinjauan Malpraktik dalam Hukum Kesehatan". Themis. Vol. 2 No. 1 October 2007. Jakarta: Pancasila University;
Mufidi, Faiz and Sri Pursetyowati. "Penyelesaian Sengketa Medik di Rumah Sakit". Jurnal Ilmu Hukum Wacana Paramarta, Vol. 8 No. 1 2009. Bandung: Faculty of Law Langlangbuana University;

Nuryanto, Arif. "Model Perlindungan Hukum Profesi Dokter", Jurisprudence, Vol. 1 No. 1. July 2012 Edition. Surakarta: Muhammadiyah Surakarta University;

Radar Bengkulu. Kasus RS Tiara Shella Juga Bergulir ke PTUN, http://radarbengkulu.web.id/ published July 5 2012, accesed on March, 102013.

Sukarjono, Bambang. "Liabilitas Hukum Pihak Rumah Sakit terhadap Pasien (Studi tentang Perlindungan Konsumen/Pasien dan Tanggung Jawab Pihak Rumah Sakit dalam Transaksi Terapeutik pada Rumah Sakit Islam Siti Aisyah Kota Madiun)". Sosial, Vol. 10 No. 2 September 2009. Malang: STIE Malangkucecwara;

Wahyudi, Setya. "Tanggung Jawab Rumah Sakit terhadap Kerugian Akibat Kelalaian Tenaga Kesehatan dan Implikasinya". Jurnal Dinamika Hukum, Vol. 11 No. 3, Septe-mber 2011. Purwokerto: Faculty of Law Jenderal Soedirman University. 